\title{
Freshness indicators for real-time quality evaluation of packaged animal origin foods: A mini-review
}

\author{
N. R. Panjagari ${ }^{1 *}$, R. K. Raman ${ }^{1}$, K. Uma ${ }^{1}$, R. Suwalka ${ }^{1}$ and E. Thomas ${ }^{1}$ \\ ${ }^{1}$ Dairy Technology Division, ICAR-National Dairy Research Institute, Karnal - 132 001, Haryana, \\ India
}

\begin{abstract}
Growing demand for safe and high-quality food has been driven by not only the rise in living standards but also consumers' worry about food safety. The lack of real-time monitoring of perishable food freshness in the supply chain has led to the growing interest in improved food packaging systems. Among them, the freshness indicators have been proving to provide real-time quality status of the packaged food. They supplement or complement the printed "Best Before" or "Expiry Date" and give consumers an informed choice. Freshness indicators work on the principle of colorimetric changes with the changes in the headspace volatile components, an essential pre-requisite, of the packaged food product. An attempt has been made to review the recent developments in the freshness indicators of animal origin foods. Further, the chemistry behind the color changes in the freshness indicators due to continuous accumulation of spoilage off-flavors, and the criteria for the fabrication and the performance evaluation of freshness indicators have been presented briefly.
\end{abstract}

Key words: Colorimetric, Fish, Freshness indicator, Intelligent packaging, Meat, Milk

\section{Highlights}

- Freshness indicators are a subclass of smart packaging systems that conveys real-time quality information to consumers.

- The information displayed is by immediate visual changes, e.g., different color intensities or the diffusion of a dye along with the indicator geometry.

- Among all the animal origin foods, fish and meat have been extensively studied while very little work on the milk and milk products concerning freshness indicators.

- Headspace total volatile basic nitrogen (TVB), carbonyl compounds (aldehydes and ketones), carbon dioxide, and $\mathrm{pH}$ have been targeted to develop the freshness indicators.

\section{Introduction}

The quality of food deteriorates in the supply chain (mainly during distribution/ storage) due to biological, chemical, biochemical, and physical processes. Delivering secure and safe food products within the maximum shelf life or "best before" or "expiry" dates of such food to consumers" is one of the main goals of food packaging. With continuous innovations in packaging science, several techniques have been emerging to meet the consumer's and other stakeholders' requirements in the supply chain. Intelligent packaging systems comprise packaging systems that monitor the conditions of food to provide information about the quality throughout the supply chain. Intelligent packaging is briefly defined as the field of packaging science that facilitates decision making at stakeholders' end by monitoring and communicating the conditions of the packaged food product (Yam and Lee, 2012). According to the European Commission Regulations, "materials and articles that are intended to monitor the condition of packaged food or the environment surrounding the food" are referred to as intelligent materials or articles

"Corresponding Author, E mail: narender.p@icar.gov.in 
Table 1. Classification of intelligent packaging systems

\begin{tabular}{|c|c|c|}
\hline Sensors & Data carriers & Indicators \\
\hline Intelligent sensors & Bar code & Time/temperature indicator \\
\hline Bio-sensors & $\begin{array}{l}\text { Radio Frequency Identification } \\
\text { (RFID)Tag }\end{array}$ & Oxygen indicator \\
\hline Gas sensors & & Carbon dioxide indicator \\
\hline Fluorescence-based sensors & & Color indicator \\
\hline $\begin{array}{l}\text { Molecularly Imprinted } \\
\text { polymer-based sensors }\end{array}$ & & Pathogen indicator \\
\hline \multirow{3}{*}{$\begin{array}{l}\text { Quartz crystal microbalance } \\
\text { based sensors }\end{array}$} & & Breakage indicator \\
\hline & & Leak indicator \\
\hline & & Freshness indicator \\
\hline
\end{tabular}

Source: Modified from Vanderroost et al. (2014)

[Commission Regulation (EC) No 450/2009]. Intelligent packaging systems are classified into sensors, data carriers, and indicators (Table 1). All of them fall within the main category of "product quality and value-improving systems," which are undoubtedly the widely used devices (Robertson and Queiroga, 2012). Indicators are a subclass of intelligent packaging tools whose characteristic feature is to convey the information through colorimetric changes. Despite the large varieties of indicators, all of them can be reasonably included within three categories: time-temperature indicators, gas indicators, and freshness indicators. From the consumers' point of view, freshness indicators help them in deciding whether or not a packaged food is to be picked from the supermarket, thus giving them an informed choice. As of now, freshness indicators development has been focused on packaged aquatic food products (fish, shrimp), meat (chicken, beef, and carabeef), fresh horticultural produce (fruits/vegetables) but little on milk and dairy products. In this article, the concept of freshness indicators and their applications to animal-origin foods is presented.

\section{Freshness indicators}

Among the intelligent or smart packaging systems, freshness indicators have been proving to provide real-time quality status of the packaged food. They supplement or complement the printed "best before" or "expiry date" and give consumers an informed choice. The genesis of the development of freshness indicators is based on the stakeholders' need for the detection of spoilage of food through targeted metabolites associated with deterioration. Qualitative, as well as quantitative determination of volatile compounds, among others, gives an array of information regarding the changes associated with the food matrices. Freshness sensors or indicators are smart devices that are in direct contact with the internal headspace of a food package. They enable the monitoring of the quality of food products throughout storage and transportation and works on the principle of colorimetric changes with the changes in the headspace volatile components of the packaged food product. It directly provides the product quality information resulting from microbial growth or chemical changes within a food product (Siro, 2012; Yoshida et al., 2014). The reaction between the microbial growth metabolites and the integrated indicators within the package provides visual evidence regarding the microbial quality of the product (Kerry et al., 2006; Kuswandi et al., 2013a). Freshness indicators can also be used to provide an estimate of the remaining shelf life of perishable products. Understanding the metabolic reactions that are associated with the quality of a food product is essential for the development 


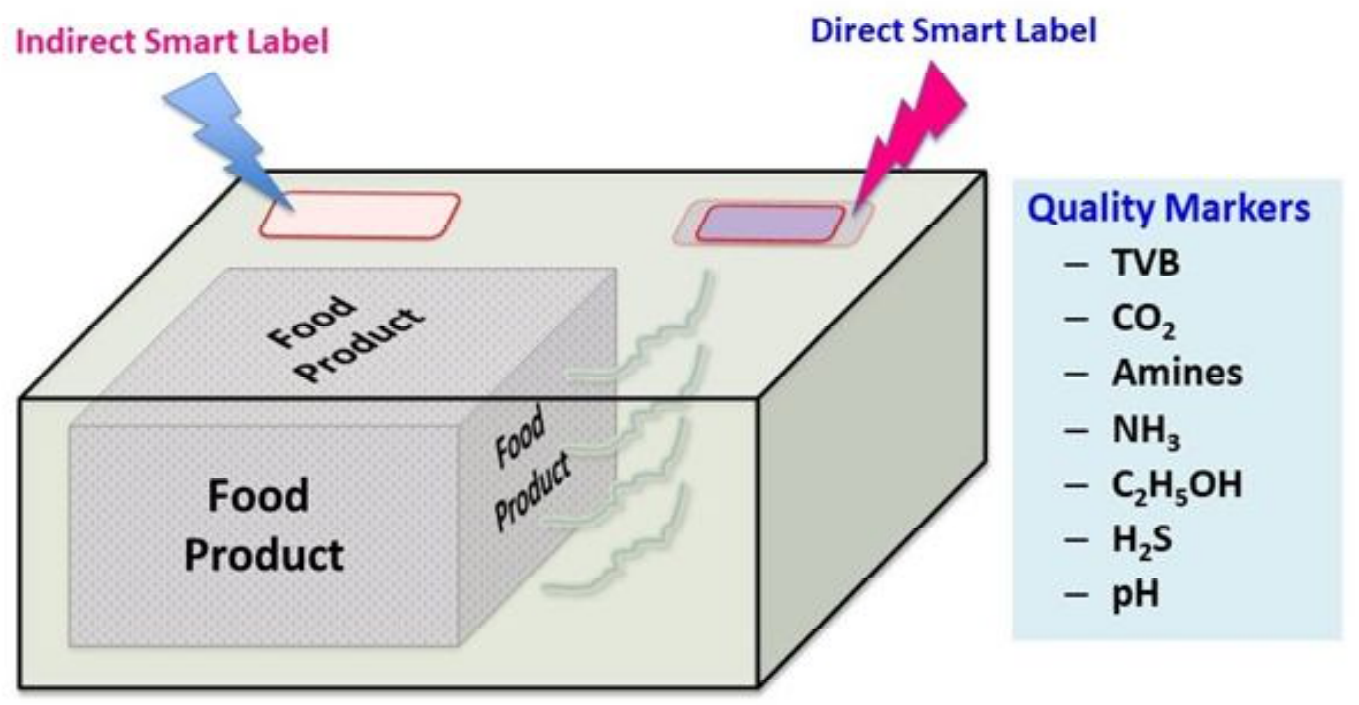

Fig. 1. Illustration of working principle of indirect and direct smart labels

of a freshness indicator. Also, integration of freshness indicator with packaging material is one of the challenging tasks. Miller et al. (2006) state that the indicator generally needs to be placed inside the food package unless the packaging material is breathable or gas-permeable.

The working principle of a freshness indicator (direct/internal smart label) is illustrated in Fig. 1. It can be seen from the figure that the volatile quality markers such as total volatile basic nitrogen (TVB), carbon dioxide $\left(\mathrm{CO}_{2}\right)$, biogenic amines, ammonia, ethyl alcohol, and hydrogen sulfide interact with the freshness indicator label affixed from inside of the package especially primary package closure/lid. The interactions between the volatile markers and the freshness indicator label components are supposed to bring about responses through visual/colorimetric changes of the label. These changes could be easily seen from the specially provided opening in the secondary package. On the other hand, the indirect/external smart labels are placed over the secondary packages for monitoring the temperature, humidity, etc. They include time-temperature indicators, humidity indicators, and also radio frequency identification (RFID) tags for the supply chain management. In the case of indirect/external also, the changes could be visualized as they may contain thermo chromic inks as in the case of time-temperature indicators. Freshness indicators may be classified based on their sensitivity into (a) indicator sensitive to $\mathrm{pH}$ change (b) indicator sensitive to volatile nitrogen compounds (c) indicator sensitive to hydrogen sulfide (d) indicator sensitive to mixed microbial metabolite (e) indicator based on the release of certain nutrient release, and (f) indicator sensitive to other headspace volatile compounds.

\section{Criteria for the fabrication of freshness indicator for a food product}

The important criteria for the selection of a freshness indicator are to identify the key volatile headspace spoilage markers for a particular food product, formulation of smart ink components, selection of suitable polymer as supporting matrix, selection of a suitable technique for fabricating the freshness indicator containing the smart ink held by the selected polymer. Since a freshness indicator is unique for a particular food product or a group of food products, the volatile spoilage markers selection assumes importance. It can be seen from the literature that total volatile basic nitrogen (TVBN) has been chosen as spoilage markers for seafood (Kuswandi et al., 2012a), fish (Pacquit et al., 2006; Kuswandi et al., 2012b; Ezati et al., 2019), pork (Golasz et al., 2013), and beef (Kuswandi et al., 2015; Shukla et al., 
2016) products while TVBN, hydrogen sulfide, and carbon dioxide for chicken (Kim et al., 2017; Zhai et al., 2019; Lu et al., 2020). In the case of egg yolk-based desserts, carbon dioxide was selected (Nopwinyuwong et al., 2010). However, for milk and milk products, aldehydes and ketones (Ziyaina et al., 2019; Goodarzi et al., 2020) have been considered as key spoilage markers for freshness indicator fabrication. Since the colorimetric changes are noticed due to the manifestations of microbial and chemical reactions in the food product over time, several dyes, both natural and synthetic have been tried. Among them redox dyes, curcumin, and anthocyanin extracted from different foods have been widely used (Kuswandi et al., 2012a; Golasz et al., 2013; Shukla et al., 2016; Zhai et al., 2019; Goodarzi et al., 2020). In general, color changes of $\mathrm{pH}$ dyes such as bromothymol blue, methyl red, bromocresol purple, bromocresol green, methyl orange, methyl yellow, and phenol red could be utilized to detect acidic/basic volatile compounds as these dyes exhibit irreversible changes in terms of structure and color upon dissolution. Among the polymer support matrices, thick papers, cellulose membrane, starch from different sources, methylcellulose, gums, hydrogels, and plastics have been utilized. Finally, for fabricating the freshness indicators, methods such as casting, absorption, or spinning method in which selected dyes or intelligent materials are mixed with a suitable solvent and fixed over the base or supporting material (Pacquit et al., 2006; Kuswandi et al., 2013b), casting, electro spinning, spin coating, ink-jet printing (Luo et al., 2021) have been adopted. Further, a list of key volatile compounds and their associated off-flavors of some animalorigin foods is presented in Table 2. Some of the studies on freshness indicators for different food products are listed in Table 3.

\section{Chemistry of interaction of freshness indicator dyes and headspace volatile compounds}

Colour changes in the freshness indicators involve the chemical interaction between the targeted headspace volatiles and the intelligent materials. Based on these molecular interactions of dyes and targeted volatiles, colorimetric recognition of several molecules is described in the previous works. Fundamentally, molecular recognition involves the interactions between molecules i.e. bond formation, acidbase interactions, $\pi-\pi$ molecular complexation, Vander-Waals interaction, and physical adsorption (Suslick et al., 2004). To monitor the warmed-off flavour defect in cooked chicken (resulting due to accumulation of pentanal, hexanal, and heptanal) a color sensor array was developed by Kim et al. (2016). The

Table 2. Major headspace volatile compounds of some animal origin foods and their corresponding off-flavors

\begin{tabular}{llll}
\hline Product & \multicolumn{1}{c}{ Compound } & Off-flavor & \multicolumn{1}{c}{ Reference } \\
\hline & Free fatty acids $\left(\mathrm{C}_{4}-\mathrm{C}_{10}\right)$ & Rancid & $\begin{array}{l}\text { Azzara and Campbell } \\
(1992)\end{array}$ \\
\cline { 2 - 4 } & $\begin{array}{l}\text { Heptanal, octanal, nonanal, } \\
\text { 2-octenal, 2-nonenal, hexanal, } \\
\text { 1-octen-3-one, 2,4-decadienal, }\end{array}$ & Oxidized & $\begin{array}{l}\text { Bassette (1976); Greig and } \\
\text { Manning (1983) }\end{array}$ \\
& $\begin{array}{l}\text { and acetaldehyde } \\
\text { Milk }\end{array}$ & & \\
\cline { 2 - 4 } & 1-Octen-3-one and octanal & Cardboard & Hammond and Seals (1972) \\
\hline & 2-Alkenals (C7-C10) and alkanals & Tallow & Badings (1991) \\
\cline { 2 - 4 } & 2- and 3-Methyl butanal & Malty & Morgan (1970a) \\
\hline
\end{tabular}


Cont. Table 2.

\begin{tabular}{|c|c|c|c|}
\hline Product & Compound & Off-flavor & Reference \\
\hline \multirow[t]{2}{*}{ Skim milk } & Methanol and methyl mercaptan & Oxidized & Allen and Parks (1975) \\
\hline & $\begin{array}{l}\text { Hydrogen sulfide, methanethiol, } \\
\text { and dimethyl sulfide }\end{array}$ & Cabbage & Jaddou et al. (1978) \\
\hline UHT milk & $\begin{array}{l}\text { 2-Heptanone, 2-nonanone, } \\
\text { octanal, nonanal, decanal, } \\
\text { 2-methyl butanal, 2-methyl } \\
\text { propanal }\end{array}$ & Stale & Zabbia et al. (2012) \\
\hline $\begin{array}{l}\text { Sterilized } \\
\text { concentrated milk }\end{array}$ & o-Amino acetophenone & Stale & Arnold et al. (1966) \\
\hline \multirow[t]{2}{*}{ Yogurt } & Acetic acid & Vinegary & Cheng (2010) \\
\hline & Acetaldehyde & $\begin{array}{l}\text { Yogurt or } \\
\text { green }\end{array}$ & Lindsay and Rippe (1986) \\
\hline \multirow[t]{2}{*}{ Butter } & Hexanal & Oxidized & $\begin{array}{l}\text { Christensen and } \\
\text { Holmer (1996) }\end{array}$ \\
\hline & $\begin{array}{l}\text { 1-Octane-3-one and } 1,5(\mathrm{Z}) \\
\text { octadien-3-one }\end{array}$ & Metallic & Swoboda and Peers (1977) \\
\hline$\underline{\text { Butter oil }}$ & 2-Nonenal & Cardboard & Widder and Grosch (1997) \\
\hline Ice cream & Dimethyl disulfide and hexanal & Putrid & Marsili (2003) \\
\hline Sodium caseinate & $\begin{array}{l}\text { n-Alkanals, furan derivatives } \\
\text { and O-amino acetophenone }\end{array}$ & Gluey & $\begin{array}{l}\text { Ramshaw and Dunstone } \\
(1969)\end{array}$ \\
\hline Cheddar cheese & Ethyl butyrate and ethyl hexanoate & Fruity & Morgan (1970b) \\
\hline $\begin{array}{l}\text { Smear coated } \\
\text { cheese }\end{array}$ & 2-Methoxy-3-isopropylpyrazines & Potato & Dumont et al. (1983) \\
\hline Milk powder & $\begin{array}{l}\text { n-Alkanals, n-alkanones, } \\
\text { furfural and benzaldehyde }\end{array}$ & Stale & $\begin{array}{l}\text { Parks and Patton (1961); } \\
\text { Schwambach and Peterson } \\
(2006)\end{array}$ \\
\hline Milk & $\mathrm{pH}$ changes & $\begin{array}{l}\text { Acidic/ } \\
\text { basic odor }\end{array}$ & Roy et al. (2021) \\
\hline Shrimp & Ammonia & $\begin{array}{l}\text { Pungent } \\
\text { (urine like) }\end{array}$ & Ding et al. (2020) \\
\hline Fish \& Pork & Ammonia & $\begin{array}{l}\text { Pungent } \\
\text { (urine like) }\end{array}$ & Ezati et al. (2021) \\
\hline Tilapia & TVB-N & Fishy & Yan et al. (2021) \\
\hline Chicken & $\mathrm{CO}_{2}$ & $\begin{array}{l}\text { Sharp } \\
\text { acidic odor }\end{array}$ & Lu et al. (2020) \\
\hline Shrimp & TVB-N, Ammonia & $\begin{array}{l}\text { Fishy; } \\
\text { Pungent } \\
\text { (urine like) }\end{array}$ & $\begin{array}{l}\text { Mohammadalinejhad } \\
\text { et al. (2020) }\end{array}$ \\
\hline Fish & TVB-N & Fishy & Wang et al. (2020) \\
\hline Fish & $\mathrm{pH} \&$ Ammonia & $\begin{array}{l}\text { Fishy/ } \\
\text { Pungent } \\
\text { (urine like) }\end{array}$ & Sani et al. (2021) \\
\hline
\end{tabular}


Table 3. Freshness indicators developed for animal origin foods

\begin{tabular}{|c|c|c|c|c|}
\hline \multirow{2}{*}{ Product } & \multirow{2}{*}{$\begin{array}{l}\text { Spoilage } \\
\text { marker }\end{array}$} & \multicolumn{2}{|c|}{ Freshness indicator components } & \multirow[b]{2}{*}{ References } \\
\hline & & $\overline{\text { Dye(s) }}$ & Supporting matrix & \\
\hline$\overline{\text { Beef }}$ & TVB-N & Lichens extracts & Litmus paper & Kuswandi et al.(2015) \\
\hline Beef & TVB-N & Anthocyanin & Filter paper & Shukla et al. (2016) \\
\hline Chicken & TVB-N & $\begin{array}{l}\text { Bromocresol } \\
\text { purple }\end{array}$ & Absorbent pad & Kim et al. (2017) \\
\hline Chicken & $\mathrm{CO}_{2}$ & $\begin{array}{l}\text { Bromothymol } \\
\text { blue/Methyl red }\end{array}$ & $\begin{array}{l}\text { Sugarcane bagasse } \\
\text { (hydrogel) }\end{array}$ & Lu et al. (2020) \\
\hline $\begin{array}{l}\text { Chicken breast, } \\
\text { Silver Carp }\end{array}$ & $\mathrm{H}_{2} \mathrm{~S}$ & Silver nanoparticles & Gellan gum & Zhai et al. (2019) \\
\hline Fish & TVB-N & Bromocresol green, & Polyethyene & Pacquit et al. (2006) \\
\hline Fish & TVB-N & Polyaniline & Polystyrene sheet & Kuswandi et al. (2012b) \\
\hline Fish & TVB-N & Anthocyanin & Chitin nanofibre & Wang et al. (2020) \\
\hline Fish & $\begin{array}{l}\text { pH \& } \\
\text { Ammonia }\end{array}$ & $\begin{array}{l}\text { Red barberry } \\
\text { anthocyanins }\end{array}$ & $\begin{array}{l}\text { Chitin nanofiber and } \\
\text { methylcellulose }\end{array}$ & Sani et al. (2021) \\
\hline Fish and Pork & Ammonia & Shikonin & Cellulose Paper & Ezati et al. (2021) \\
\hline Golden drop & $\mathrm{CO}_{2}$ & $\begin{array}{l}\text { Bromothymol blue } \\
\text { and Methyl red }\end{array}$ & Methylcellulose & $\begin{array}{l}\text { Nopwinyuwong et al. } \\
(2010)\end{array}$ \\
\hline Milk & $\begin{array}{l}\text { Volatile } \\
\text { aldehydes } \\
\text { and ketones }\end{array}$ & Schiff reagent & $\begin{array}{l}\text { Silicon dioxide } \\
\text { nanoparticles }\end{array}$ & Ziyaina et al. (2019) \\
\hline Milk & $\mathrm{pH}$ change & $\begin{array}{l}\text { Black carrot } \\
\text { anthocyanin }\end{array}$ & Starch & Goodarzi et al. (2020) \\
\hline Milk & $\mathrm{pH}$ & Shikonin\& Propolis & $\begin{array}{l}\text { Gelatin \& } \\
\text { Carrageenan }\end{array}$ & Roy et al. (2021) \\
\hline Milk and Fish & $\begin{array}{l}\text { Volatile acids } \\
\text { and bases }\end{array}$ & $\begin{array}{l}\text { Red radish } \\
\text { anthocyanin }\end{array}$ & $\begin{array}{l}\text { Gelatin, Gellan gum } \\
\text { Cassava starch }\end{array}$ & Zhai et al. (2018) \\
\hline Pork & TVB-N & Anthocyanin & Cellulose paper & Golasz et al. (2013) \\
\hline $\begin{array}{l}\text { Rainbow Trout } \\
\text { (Fish) }\end{array}$ & $\begin{array}{l}\text { TVB-N; } \\
\text { Ammonia }\end{array}$ & Alizarin & Cellulose Membrane & Ezati et al. (2019) \\
\hline Shrimp & TVB-N & Curcumin & $\begin{array}{l}\text { Modified cellulose \& } \\
\text { Polyvinyl Alcohol }\end{array}$ & $\begin{array}{l}\text { Kuswandi et al. } \\
\text { (2012a) }\end{array}$ \\
\hline Shrimp & Ammonia & Acidochromic dye & Bacterial cellulose & Ding et al. (2020) \\
\hline Shrimp & TVB-N & $\begin{array}{l}\text { Echium amoenum } \\
\text { (flower) }\end{array}$ & $\begin{array}{l}\text { Polymeric chitosan } \\
(\mathrm{CH})\end{array}$ & $\begin{array}{l}\text { Mohammadalinejhad } \\
\text { et al. (2020) }\end{array}$ \\
\hline Tilapia & TVB-N & $\begin{array}{l}\text { Butterfly pudding } \\
\text { flower } \\
\text { (Clitoriaternatea } L \text { ) }\end{array}$ & & Yan et al. (2021) \\
\hline
\end{tabular}

author reported that the developed sensor array was based on the cross-reactive mechanism between selected dyes mixed with 2-4 DNPH in presence of acid. The color changes in the array is due to the formation of hydrazide derivatives and water. Feng et al. (2010) developed a method for the detection of formaldehyde (gas) which works on the interaction between formaldehyde and primary amines leading to colorimetric changes. The 
detection method was based on nucleophilic addition of an amine to the aldehyde, forming an imine via a carbinolamine intermediate and the formed imine generates a colour change. Ziyaina et al. (2019) developed a freshness indicator (nanosensor for the detection of spoilage of milk). The reported sensor was developed using silicon dioxide nanoparticles and Schiff reagent and changes colour from colourless to magenta. Further, it was reported that the reaction involves the addition of the nucleophile group of the Schiff's reagent to the carbonyl group of an aldehyde which brought the colour changes from colourless to magenta in the response to milk spoilage owing to the extreme bulkiness of this nucleophile. Further, the authors evaluated the indicator response with ketone and suggested that a ketone that is more sterically crowded than an aldehyde at the carbonyl carbon, does not react with Schiff's reagent and does not produce the magenta colour.

\section{Freshness indicators of fish and seafood}

Freshness indicators are most commonly used in the areas of fish/seafood and flesh foods, as these foods produce a characteristic odor produced during decomposition, either due to microbial attack on the nutrients or postdeath physiological changes. Freshness indicators for animal-based foods are mainly based on $\mathrm{pH}$ changes, TVBN compounds, hydrogen sulfide, carbon dioxide, and mixed microbial metabolites. Many a times, colorimetric indicator labels for fish/seafood and meat are based on a specific reaction with TVBN formed during the storage. To monitor the warmed-off flavor defect in cooked chicken (due to the accumulation of pentanal, hexanal, and heptanal) a color sensor array was developed by Kim et al. (2016). The authors reported that the developed sensor array was based on the cross-reactive mechanism between selected dyes mixed with 2-4 DNPH in presence of acid. The array responds to the aldehydes based on the specific reaction between aldehydes and DNPH that leads to the formation of hydrazine derivatives and $\mathrm{H}_{2} \mathrm{O}$ which causes color changes. Kim et al. (2017) developed a freshness indicator to monitor the chicken freshness. The authors reported that the developed indicator relies on bromocresol purple dye immobilized with polyvinyl alcohol and a high moisture-absorbing material. The color of the indicator changes from yellow to blue and finally purple to indicate spoilage. Further, it was reported that sensor color change was in positive correlation with $\mathrm{pH}$ change with no migration of dye from the indicator onto the surface of chicken. Listyarini et al. (2018b) developed a freshness indicator film for monitoring meat spoilage that changes its colour from brownish violet to light yellowishbrown after its contact with ammonia gas in $\mathrm{pH}$ ranges of 7-11.

Integrating cellulose modified with acidochromic dye (ARC) into polyvinyl alcohol (PVA), Ding et al. (2020) produced an intelligent indicator with high strength and outstanding leakage resistance. At various $\mathrm{pH}$ levels, the produced indicator showed unique color changes. The dye was reported to be leakage-free in the acid solution and just 0.7 percent of dye was reported to be leaked in the alkaline solution, indicating that this $\mathrm{pH}$ film sensor has high leakage resistance. The PVA/ ARC film sensor changed its color from yellow to brown within $24 \mathrm{~h}$, demonstrating the sensor's ability to monitor the shrimp quality in real-time. To monitor the deterioration of fresh aqua cultured rainbow trout (Oncorhynchus mykiss) held at chilled temperature, Ezati et al. (2019) developed a $\mathrm{pH}$-sensitive indicator employing cellulose and starch and alizarin as a natural color. The indicator shows color changes from yellow to purple in alizarin-starch-cellulose indicator (ASC) and dark red in cellulose papers coated with alizarin (AC) in response to spoilage throughout a larger $\mathrm{pH}$ range of 2-11. The indicator shows color changes from yellow to purple in alizarin-starch-cellulose indicator (ASC) and dark red in cellulose papers coated with alizarin (AC) in response to spoilage 
throughout a larger $\mathrm{pH}$ range of 2-11. Furthermore, both indicators were observed to have a high sensitivity and color reaction to ammonia, confirming a valid association between microbial growth, TVB-N production, $\mathrm{pH}$ changes, and indicator color changes. An innovative indicator was produced by Ezati et al. (2021) by adsorbing a pigment (naphthoquinone, shikonin) on cellulose paper to evaluate the freshness of fish and pork. Depending on the $\mathrm{pH}(2-12)$, the shikoninadsorbed color indicator paper changed its color from red to blue and also changed the color sensitively to ammonia gas. It was reported that the color change of the indicator was closely related to the increase in the $\mathrm{pH}$ of fish and pork samples during storage at room temperature and the results showed a strong correlation between the color change of the indicator and the $\mathrm{pH}$ change of the sample.

\section{Freshness indicators of meat}

Carbon dioxide and TVBN compounds produced in meat products during storage have been widely considered as spoilage indicators for meat-based products. Yoshida et al. (2014) developed a colorimetric chitosan bio-based $\mathrm{pH}$ indicator for detecting n-butyrate, L-lactic acid, D-lactate, and acetic acid derived from microbial growth. Carbon dioxide $\left(\mathrm{CO}_{2}\right)$ indicators consisting of aqueous solutions of chitosan or whey protein isolate were used to detect the changes in transparency of the indicator due to the $\mathrm{pH}$-dependent whey (Jung et al., 2012). Rukchon et al. (2014) developed a colorimetric freshness indicator for skinless chicken breast spoilage and reported that the indicator responded to $\mathrm{CO}_{2}$ and changes its color. The indicator response correlated well with microbial growth and the number of volatile compounds generated thus enabling real-time monitoring of food spoilage. Shukla et al. (2015) developed a colorimetric freshness indicator to monitor the freshness of buffalo meat during refrigerated storage. The fabricated indicator changed its color from yellow to blue as the meat quality deteriorated in terms of accumulated TVBN in the package headspace. Further, based on the changes in the color, the authors developed a color scale to measure the degree of freshness. Chen et al. (2019) developed a freshness indicator label for assessing meat freshness. The indicator label was made by mixing the suspension of methylcellulose, polyethylene glycol-6000, and $\mathrm{pH}$-sensitive dyes either singly or in combination. Indicator labels change their color from blue to yellow in response to spoilage. The color response was correlated with changes in $\mathrm{pH}, \mathrm{TVB}-\mathrm{N}$ content, and aerobic plate counts of pork. Further, using statistical models color changes of the label were successfully predicted for TVB-N contents and aerobic plate counts of pork. A freshness indicator based on high moisture-binding materials was developed by Kim et al. (2017) to monitor the chicken freshness. The color of the indicator containing bromocresol purple changes from yellow to blue and finally purple to indicate spoilage which positively correlated with $\mathrm{pH}$ change. Further, it was reported there was no migration of dye from the indicator onto the surface of chicken was documented. Lee et al. (2019) developed a freshness indicator to monitor chicken breast spoilage. Color changes in the indicator were monitored with the naked eye as well as smartphone and processed digitally. Concentration-based optimal color changes in indicators were reported in simulated conditions using 8 different concentrations of trimethylamine.

\section{Freshness indicators of milk products}

Studies on the development of freshness indicators on milk and milk products are negligible compared to fish and meat. Kulchan et al. (2016) developed a novel mixed pH dyebased colorimetric indicator for monitoring rancidity reaction in infant milk powder formula. The indicator was based on $\mathrm{pH}$-sensitive dyes either singly or in combination which was supported on methylcellulose and hydroxypropyl methylcellulose as fabricating material. Developed indicator monitors the 
rancidity by sensing hexanal and acetic acid as spoilage metabolite and responds through a color change from bright green for fresh to orange as an indication of warning. Color changes of the indicator were in agreement with the chemical quality indices like peroxide value and free fatty acids and sensory score. Among the dairy products manufactured in Indian sub-continent, traditional dairy products have social, cultural and economic importance. Although majority of them are produced at small scale with the continuous research and development (R\&D) efforts from both academia and industry, they are now being produced at industrial scale with improved processes and packaging systems. Improved packaging systems such as modifying the package internal atmosphere (air) with near zero oxygen content and flushing it with inert nitrogen gas (modified atmosphere packaging); evacuating the entire ambient air from the package (vacuum packaging); and utilization of oxygen scavengers for selective removal of oxygen from the headspace (active packaging) are some of the popular ones. In addition, improved package design (presentation of products and label graphics) has been another area where the manufacturers have been focusing to meet the consumers' demands. However, the use of novel packaging systems such as freshness indicators which can give a non-destructive and real-time quality status details to the consumers and helps in having an informed choice at the supermarkets' shelves, has not yet been adopted mainly due to the lack of available technologies. In view of the importance and potential export market for traditional Indian dairy products, studies have been initiated at ICAR-NDRI in the authors' laboratory. The freshness indicators for Khoa, Sandesh, and Dahi have been developed and filed for protection as a patent. Hence, we may expect these indicators in the market in the near future to address the food safety concerns.

\section{Freshness indicators of other animal origin foods}

Nopwinyuwong et al. (2010) developed a freshness indicator to monitor the quality of
Golden drop, an egg yolk-based intermediate moisture Thai dessert which could serve as a "chemical barcode" for real-time monitoring of spoilage. The indicator contained mixed $\mathrm{pH}$ sensitive dyes, bromothymol blue, and methyl red that respond to carbon dioxide $\left(\mathrm{CO}_{2}\right)$ as a spoilage metabolite through visible color change, which correlated well with $\mathrm{CO}_{2}$ levels. Listyarini et al. (2018a) assessed the indicator response against the shrimp volatiles during storage $(2 \mathrm{~h}, 17 \mathrm{~h}$ and $24 \mathrm{~h})$ by placing the indicator label in a clear glass vial and observed color change in the indicator label due to decay of spoilage.

\section{Performance evaluation of freshness indicators}

Freshness indicators react selectively with the volatile compounds in the headspace of the package and respond through a visual color change. By reviewing the literature, it was observed that the sensitivity of the freshness indicators is mainly evaluated by three different measures namely color response (a) to different $\mathrm{pH}$ (b) to a target analyte in a liquid phase (c) to a target analyte in a vapor phase. In the colorimetric response of the indicator labels to different $\mathrm{pH}$, an indicator is evaluated due to changes in the acidity or basicity of the package environment. Zhai et al. (2019) evaluated the response of a freshness indicator of milk and fish based on the changes in acidity. The indicator film changes its color from orangered to yellow in the $\mathrm{pH}$ range of 2-12. Listyarini et al. (2018 b) developed a freshness indicator film for monitoring meat spoilage that changes its color due to changes in the basicity of the package environment from brownish violet to light yellowish-brown after contact with ammonia gas in $\mathrm{pH}$ ranges of 7-11. A universal $\mathrm{pH}$ indicator based on halochromic dyes (phenol red, methyl red, bromothymol blue, phenolphthalein, and bromocresol green) was developed to assess the $\mathrm{pH}$ variations. The developed indicator was capable of detecting $\mathrm{pH}$ values from 1-10 indicating a typical color at each pH (Agarwal et al., 2012). In 
colorimetric response to a target analyte in the liquid phase method, a definite amount of target analyte is directly dropped on the surface of the indicator label and the color changes in the indicator label are recorded and analyzed. Listyarini et al. (2018a) developed a freshness indicator film for monitoring shrimp spoilage and its response to liquid ammonia $(0.8 \mathrm{M})$ was evaluated by placing the film (disc-shaped) on the surface of $\mathrm{pH}$ buffer solutions ( $\mathrm{pH}$ 7-11) in a petri dish, and the color changes were recorded and analyzed. The response of freshness indicators is also assessed by exposing the indicators to a known concentration of gaseous analyte at a particular temperature by placing them in a gas-tight clear glass vial. This method is also suitable to measure the concentrationdependent color changes. Nopwinyuwong et al. (2010) assessed the concentrationdependent color changes in freshness indicator intended to measure the freshness of golden drop (a Thai dessert) and reported a brilliant color transition in the indicator label due to exposure to varying concentrations of $\mathrm{CO}_{2}$.

\section{Commercially available freshness indicators}

According to Kuswandi (2017), freshness sensors are classified into three types based on the number of sensors they contain: single, dual, and multiple. Single sensors are those freshness sensors in which only one sensor isused for sensing the target analyte and communicating it to the observer. While the dual freshness sensors/ indicators are those in which two sensors are employed refer to each other in detecting the target analyte and also communicating it to the consumer about the quality of food. The third one i.e. multiple freshness sensors/indicator consist of more than two sensors which ultimately make an array to make a pattern that can be utilized as a tool for sensing the analyte and communication for the consumers. However, currently, singletype freshness sensors are common as compared to dual and multiple type sensors are commercially popular. Commercial applications of freshness indicators include SensorQ ${ }^{\text {TM }}$ by FQSI Inc (United States of America), which senses spoilage in fresh meat and poultry products and Toxinguard $^{\circledR}$ by Toxin Alert Inc (Canada) to monitor Pseudomonas sp. growth (Kerry and Butler, 2008). COX Technologies, USA launched Fresh Tag® colorimetric indicator labels that react with volatile amines produced during the storage of fish and seafood products (Hogan and Kerry, 2008). The Vanprob Company developed food fresh indicators (time-temperature based. Insignia Technologies, produced NOVAS freshness indicator, which is easily incorporated into film lid (https://www.insigniatechnologies.com).

\section{Freshness indicator development: Challenges}

Freshness Indicators offers more direct information than other contemporary indicators such as TTIs and leak indicators. Despite this apparent advantage freshness indicators have generally been far less successful than TTIs in gaining a market foothold (Smolander, 2008). Other loopholes of freshness indicators are color changes due to contamination can result in false-positive results (products may not have any significant sensory or quality deterioration). The presence of certain target individual metabolites is not necessarily an indication of poor quality and chances are there for a generation of false-negative or false-positive results, which may dissuade consumers regarding product quality (Hogan and Kerry, 2008). To eradicate all these hindrances, the developed indicator must be characterized with the targeted metabolite or analyte in simulated conditions, and developed color, as well as their intensity, should be cross-checked with realtime product spoilage during storage.

\section{Conclusion}

Delivering safe food products within the claimed shelf life or "best before" or "expiry" dates of such food is one of the main goals of food packaging. Several techniques have been emerging to meet the consumer's and other stakeholders' food safety and assurance in the supply chain. On-package food freshness indicators have been a result of continuous 
developments in packaging science that meet that demand. Several volatile compounds especially TVBN, carbon dioxide, ammonia, and carbonyl compounds (ketones and aldehydes) have been considered for the fabrication of freshness indicators for perishable animal origin foods. Further, a wide range of polymer support matrices is compatible with freshness indicator development. Since already a good number of freshness indicators are available in the global market, great scope exists for the Indian fresh and processed traditional animal origin foods.

\section{REFERENCES}

Agarwal A, Raheja A, Natarajan TS and ChandraTS, 2012. Development of universal $\mathrm{pH}$ sensing electrospun nanofibers. Sens Actuators B: Chem, 161(1): 1097-1101, doi: 10.1016/ j.snb.2011.12.027

Allen C and Parks OW, 1975. Evidence for methional in skim milk exposed to sunlight. J Dairy Sci, 58(11): 1609-1611, doi: 10.3168/jds.S00220302(75)84758-8

Arnold RG, Libbey LM and Day EA, 1966. Identification of components in the stale flavor fraction of sterilized concentrated milk. J Food Sci, 31(4): 566-573, doi: 10.1111/j.13652621.1966.tb01906.x

Azzara CD and Campbell LB, 1992. Off-flavors of dairy products. Dev Food Sci, 28: 329-374, doi: 10.1016/B978-0-444-88558-6.50018-0

Badings HT, 1991. Milk. In: Volatile Compounds in Foods and Beverages, Edited by Maarse Henk and Marcel Dekker, New York, pp 1-106

Bassette R, 1976. Effects of light on concentrations of some volatile materials in milk. J Milk Food Technol, 39(1): 10-12, doi: 10.4315/0022-274739.1.10

Cheng H, 2010. Volatile flavor compounds in yoghurt: A review. Crit Rev Food Sci Nutr, 50(10): 938950, doi: 10.1080/10408390903044081

ChenHZ, Zhang M, Bhandari B and Yang CH, 2019. Development of a novel colorimetric food package label for monitoring lean pork freshness. LWT-Food Sci Tech, 99(4): 43-49, doi: 10.1016/ j.lwt.2018.09.048

Christensen TC and Holmer GK, 1996. GC/MS analysis of volatile aroma components in butter during storage in different catering packaging.
Conflict of interest: Authors have no conflict of interest in this study.

Author's contribution: NRP: Conceptual framework of the manuscript, drafting, production of illustration/figure and revision of the manuscript; RKR: Contribution in compiling studies for this review and drafting; $\mathrm{KU}$ : Contribution in compiling studies for this review and drafting; RS: Contribution in compiling studies for this review and drafting; ET: Contribution in compiling studies for this review, drafting and tabulation of studies.

Milchwissenschaft, 51(3): 134-139

Commission Regulation (EC),2009. No 450/2009 of 29 May 2009 on active and intelligent materials and articles intended to come into contact with food (Text with EEA relevance) (legislation.gov.uk)

Ding L, Li X, Hu L, Zhang Y, Jiang Y et al., 2020. A naked-eye detection polyvinyl alcohol/ cellulose-based $\mathrm{pH}$ sensor for intelligent packaging. Carbohydr Polym, 233: 115859, doi: 10.1016/j.carbpol.2020.115859

Dumont JP, Mourges R and Adda J, 1983. Potato like off flavour in smear coated cheese. In: Sensory Quality in Foods and Beverages: Definition, Measurement and Control, Ed. By AA Williams, RK Atkins. Ellis Horwood: Chichester, pp 424-428

Ezati P, Bang YJ and Rhim JW, 2021. Preparation of a shikonin-based $\mathrm{pH}$-sensitive color indicator for monitoring the freshness of fish and pork. Food Chem, 337: 127995, doi: 10.1016/ j.foodchem.2020.127995

Ezati P, Tajik H, Moradi M and Molaei R, 2019. Intelligent $\mathrm{pH}$-sensitive indicator based on starchcellulose and alizarin dye to track freshness of rainbow trout fillet. Int J Biol Macromol, 132: 157-165, doi: 10.1016/j.ijbiomac.2019.03.173

Feng L, Musto CJ and Suslick KS, 2010. A simple and highly sensitive colorimetric detection method for gaseous formaldehyde. J Am Chem Soc, 132(12): 4046-4047, doi: 10.1021/ ja910366p

Golasz LB, Silva JD and Silva SBD, 2013. Film with anthocyanins as an indicator of chilled pork deterioration. Food Sci Technol, 33(4): 155-162, doi: 10.1590/S0101-20612013000500023 
Goodarzi MM, Moradi M, Tajik H, Forough M, Ezati $\mathrm{P}$ et al., 2020. Development of an easy-to-use colorimetric $\mathrm{pH}$ label with starch and carrot anthocyanins for milk shelf-life assessment. Int J Biol Macromol, 153: 240-247, doi: 10.1016/ j.ijbiomac.2020.03.014

Greig BD and Manning DJ, 1983. Acetaldehyde and the acceptability of pasteurized milk stored under refrigeration. Int J Dairy Technol, 36(2): 49-52, doi: $10.1111 / \mathrm{j} .1471-0307.1983 . t b 02536 . x$

Hammond EG and Seals RG, 1972. Oxidized Flavor in Milk and Its Simulation. J Dairy Sci, 55(11): 15671569, doi: 10.3168/jds.S0022-0302(72)85721-7

Hemavathy J and Prabhakar JV, 1973. Changes in the carbonyl composition of a milk based sweetmeatburfi during preparation and storage. J Food Sci Technol, 10(4): 156-160

Hogan SA and Kerry JP, 2008. Smart packaging of meat and poultry products. Smart Packaging Technologies for Fast Moving Consumer Goods. John Wiley \& Sons Ltd: West Sussex, England, pp 33-59, available in https://www.insigniatechnologies.com $\left[27^{\text {th }}\right.$ Sept., 2021]

Jaddou HA, Pavey JA and Manning DJ, 1978. Chemical analysis of flavour volatiles in heat-treated milks. J Dairy Res, 45(3): 391-403, doi: 10.1017/ S0022029900016617

Jung J, Puligundla P and Ko S, 2012. Proof-of-concept study of chitosan-based carbon dioxide indicator for food packaging applications. Food Chem, 135(4): 2170-2174, doi: 10.1016/ j.foodchem.2012.07.090

Kerry J and Butler P, 2008. Smart Packaging Technologies for Fast Moving Consumer Goods. John Wiley and Sons: West Sussex, England

Kerry JP, O'grady MN and Hogan SA, 2006. Past, current and potential utilisation of active and intelligent packaging systems for meat and muscle-based products: A review. Meat Sci, 74(1): 113-130, doi: 10.1016/j.meatsci.2006.04.024

Kim D, Lee S, Lee K, Baek S and Seo J, 2017. Development of a $\mathrm{pH}$ indicator composed of high moisture-absorbing materials for real-time monitoring of chicken breast freshness. Food Sci Biotechnol, 26(1): 37-42, doi: 10.1007/s10068017-0005-6

Kim SY, Li J, Lim NR, Kang BS and Park HJ, 2016. Prediction of warmed-over flavour development in cooked chicken by colorimetric sensor array. Food Chem, 211: 440-447, doi: 10.1016/ j.foodchem.2016.05.084

Kulchan R, Boonsupthip W, Jinkarn T and Suppakul
P, 2016. Developing a novel colorimetric indicator for monitoring rancidity reaction and estimating the accelerated shelf life of oxygensensitive dairy products. Int Food Res J, 23(3): 1092-1099

Kumar G and Srinivasan MR, 1981. Identification and estimation of some volatile carbonyls in three types of khoa by GLC. J Food Sci Technol, 18: $157-158$

Kumar G and Srinivasan MR, 1984. Identification and estimation of some volatile carbonyls in three types of fresh chhana. Indian J Dairy Sci, 37(1): 33-35

Kuswandi B, 2017. Freshness sensors for food packaging. Ref Module Food Sci, Elsevier, Amsterdam, The Netherlands, 1-11, doi: 10.1016/ B978-0-08-100596-5.21876-3

Kuswandi B, Damayanti F, Jayus J, Abdullah A and Heng LY, 2015. Simple and low-cost on-package sticker sensor based on litmus paper for real-time monitoring of beef freshness. J Math Fundam Sci, 47(3): 236-251

Kuswandi B, Kinanti DP, Abdullah JA and Heng LY, 2013a. Simple and low-cost freshness indicator for strawberries packaging. Acta Manilana, 61: 147-159

Kuswandi B, Larasati TS, Abdullah A and Heng LY, 2012a. Real-time monitoring of shrimp spoilage using on-package sticker sensor based on natural dye of curcumin. Food Anal Methods, 5(4): 881889

Kuswandi B, Maryska C, Abdullah A and Heng LY, 2013b. Real time on-package freshness indicator for guavas packaging. J Food Meas Charact, 7(1): 29-39

Kuswandi B, Restyana A, Abdullah A, Heng LY and Ahmad M 2012b. A novel colorimetric food package label for fish spoilage based on polyaniline film. Food Control, 25(1): 184-189, doi: 10.1016/j.foodcont.2011.10.008

Lee K, Baek S, Kim D and Seo J, 2019. A freshness indicator for monitoring chicken-breast spoilage using a Tyvek® sheet and RGB color analysis. Food Packag Shelf Life, 19: 40-46

Li Y, Zhang L and Wang W, 2012. Formation of aldehyde and ketone compounds during production and storage of milk powder. Molecules, 17(8): 9900-9911, doi: 10.3390/molecules 17089900

Lindsay RC and Rippe JK, 1986. Enzymic generation of methanethiol to assist in the flavor development of cheddar cheese and other foods. 
In: Biogeneration of Aromas. Ed. Parliament $\mathrm{H}$ and Croteau. American chemical society: Washington, pp 286-308, doi: 10.1021/BK-19860317.CH023

Listyarini A, Imawan C, Amalia B and Fauzia V, 2018b. Chitosan/nanocellulose with natural dye as a new developed colorimetric film for ammonia detection. In AIP Conference Proceedings, AIP Publishing LLC, 2023(1): 20 -28

Listyarini A, Sholihah W and Imawan C, 2018a. A paper-based colorimetric indicator label using natural dye for monitoring shrimp spoilage. In IOP Conference Series: Materials Science and Engineering, IOP Publishing Ltd., 367(1): 012045

Lu P, Yang Y, Liu R, Liu X, Ma J et al., 2020. Preparation of sugarcane bagasse nanocellulose hydrogel as a colourimetric freshness indicator for intelligent food packaging. Carbohydr Polym, 249: 116831, doi: 10.1016/j.carbpol.2020.116831

Luo X, Ho I, Brankovan S and Lim LT, 2021. Inkjetprinted gradient colorimetric indicators for monitoring fish freshness. Food Packag Shelf Life, 29: 100719, doi: 10.1016/j.fpsl.2021.100719

Marsili RT, 2003. Flavours and off flavours in dairy foods. In: Encycolpedia of Dairy Science. Ed. Roginski, H., Fuquay, J. W. and Fox, P. F. Academic Press, London, pp 1069-1081

Miller DW, Wilkes JG and Conte ED, 2006. With indicator calorimetrically responsive at freezing temperatures to volatile bases generated by food decomposition. U.S. Patent No. 7,014,816. Patent and Trademark office, Washington, DC: U.S

Mohammadalinejhad S, Almasi $\mathrm{H}$ and Moradi M, 2020. Immobilization of Echium amoenum anthocyanins into bacterial cellulose film: A novel colorimetric $\mathrm{pH}$ indicator for freshness/ spoilage monitoring of shrimp. Food Control, 113: 107169, doi: 10.1016/ j.foodcont.2020.107169

Moid L, Etievant P, Langlois D, Dekimpe J and Addeo F, 1994. Detection of powerful odorants in heated milk by use of extract dilution sniffing analysis. J Dairy Res, 61(3): 385-394, doi: 10.1017/ S0022029900030806

Morgan ME, 1970a. Microbial flavor defects in dairy products and methods for their simulation. I. Malty flavor 1, 2. J Dairy Sci, 53(3): 270-272, doi: 10.3168/jds.S0022-0302(70)86195-1

Morgan ME, 1970b. Microbial flavor defects in dairy products and methods for their simulation. I. Fruity flavor 1, 2. J Dairy Sci, 53(3): 273-275, doi:
10.3168/jds.S0022-0302(70)86195-1

Nopwinyuwong A, Trevanich S and Suppakul P, 2010. Development of a novel colorimetric indicator label for monitoring freshness of intermediatemoisture dessert spoilage. Talanta, 81(3): 11261132, doi: 10.1016/j.talanta.2010.02.008

Pacquit A, Lau KT, Mclaughlin H, Frisby J, Quilty B et al., 2006. Development of a volatile amine sensor for the monitoring of fish spoilage. Talanta, 69(2): 515-520, doi: 10.1016/ j.talanta.2005.10.046

Parks OW and Patton S, 1961. Volatile carbonyl compounds in stored dry whole milk. J Dairy Sci, 44(1): 1-9, doi: 10.3168/jds.S0022-0302(61) 89691-4

Ramshaw EH and Dunstone EA, 1969. Volatile compounds associated with the off-flavour in stored casein. J Dairy Res, 36(2): 215-223, doi: 10.1017/s0022029900012711

Robertson GL and Queiroga RDCRDE, 2012. Food Packaging: Principles and Practice. CRC Press: Florida, USA

Roy S and Rhim JW, 2020. Preparation of gelatin/ carrageenan-based color-indicator film integrated with shikonin and propolis for smart food packaging applications. ACS Appl Bio Mater, 4(1):770-779, doi: 10.1021/acsabm. $0 \mathrm{c} 01353$

Rukchon C, Nopwinyuwong A, Trevanich S, Jinkarn T and Suppakul P, 2014. Development of a food spoilage indicator for monitoring freshness of skinless chicken breast. Talanta, 130: 547-554, doi: 10.1016/j.talanta.2014.07.048

Sani, MA, Tavassoli M, Hamishehkar $\mathrm{H}$ and McClements DJ, 2021. Carbohydrate-based films containing $\mathrm{pH}$-sensitive red barberry anthocyanins: application as biodegradable smart food packaging materials. Carbohydr Polym, 255: 117488, doi: 10.1016/j.carbpol.2020.117488

Schwambach SL and Peterson DG, 2006. Reduction of stale flavor development in low-heat skim milk powder via epicatechin addition. J Agric Food Chem, 54(2): 502-508, doi: 10.1021/jf0519764

Shukla V, Kandeepan G and Vishnuraj MR, 2015. Development of on-package indicator sensor for real-time monitoring of buffalo meat quality during refrigeration storage. Food Anal Methods, 8(6): 1591-1597, doi: 10.1007/s12161-0140066-6

Shukla V, Kandeepan G, Vishnuraj MR and Soni A, 2016. Anthocyanins based indicator sensor for intelligent packaging application. Agric 
Res, 5(2): 205-209, doi: 10.1007/s40003-0160211-0

Siro I, 2012. Active and intelligent packaging of food. In: Progress in food preservation. Ed. Bhat, R., Alias, A. K. and Paliyath, G. John Wiley and Sons Inc: New York, pp 23-48

Smolander M, 2008. Freshness indicators for food packaging. In Smart Packaging Technologies for Fast Moving Consumer Goods. Ed. Kerry, J. and Butler. Wiley Publishing company: US, pp 111128

Suslick KS, Rakow NA and Sen A, 2004. Colorimetric sensor arrays for molecular recognition. Tetrahedron, 60(49): 11133-11138, doi: 10.1016/j.tet.2004.09.007

Swoboda PA and Peers KE, 1977. Volatile odorous compounds responsible for metallic, fishy taint formed in butterfat by selective oxidation. J Sci Food Agric, 28(11): 1010-1018, doi: 10.1002/ jsfa. 2740281110

Vanderroost M, Ragaert P, Devlieghere F and De Meulenaer B, 2014. Intelligent food packaging: The next generation. Trends Food Sci Technol, 39(1): 47-62, doi: 10.1016/j.tifs.2014.06.009

Wang H, Li B, Ding F and Ma T, 2020. Improvement of properties of smart ink via chitin nanofiber and application as freshness indicator. Prog Org Coat, 149: 105921, doi: 10.1016/j.porgcoat. 2020.105921

Widder S and Grosch W, 1997. Precursors of 2-nonenals causing the cardboard off-flavour in butter oil. Mol Nutr Food Res, 41(1): 42-45, doi: 10.1002/food.19970410111

Yam KL and Lee DS, 2012. Emerging food packaging technologies- principles and practices. Woodland publishing: Cambridge, UK

Yan J, Cui R, Qin Y, Li L and Yuan M, 2021. A pH indicator film based on chitosan and butterfly pudding extract for monitoring fish freshness. Int J Biol Macromol, 177: 328-336, doi: 10.1016/ j.ijbiomac.2021.02.137

Yoshida CM, Maciel VBV, Mendonça MED and Franco TT, 2014. Chitosan biobased and intelligent films: Monitoring $\mathrm{pH}$ variations. LWT-Food Sci Technol, 55(1): 83-89, doi: 10.1016/j.lwt.2013.09.015

Zabbia A, Buys EM and De Kock HL, 2012. Undesirable sulphur and carbonyl flavor compounds in UHT milk: A review. Critic Rev Food Sc Nutr, 52(1): 21-30, doi: 10.1080/ 10408398.2010.487166

Zhai X, Li Z, Shi J, Huang X, Sun Z et al., 2019. A colorimetric hydrogen sulfide sensor based on gellan gum-silver nanoparticles bionanocomposite for monitoring of meat spoilage in intelligent packaging. Food Chem, 290: 135-143, doi: 10.1016/j.foodchem.2019.03.138

Zhai X, Li Z, Zhang J, Shi J, Zou X et al., 2018. Natural biomaterial-based edible and $\mathrm{pH}$-sensitive films combined with electrochemical writing for intelligent food packaging. J Agric Food Chem, 66(48): 12836-12846, doi:10.1021/acs.jafc. $8 \mathrm{~b} 04932$

Ziyaina M, Rasco B, Coffey T, Ünlü G and Sablani SS, 2019. Colorimetric detection of volatile organic compounds for shelf-life monitoring of milk. Food Control, 100: 220-226, doi: 10.1016/ j.foodcont.2019.01.018

Received - 30.09.2021, Accepted - 22.11.2021, Published - 01.12.2021

Section Editor: Prof. M. K. Sanyal, Member, Editorial Board 